\title{
Scenario model of reproduction of the financial potential of institutional sectors as a tool for forecasting the economic sustainability of regional systems
}

\author{
Ilya Naumov* \\ Ural State University of Economics, 620144, 8 Marta Str., 62/45, Ekaterinburg, Russia
}

\begin{abstract}
The paper presents a methodological approach to the formation of a scenario model of reproduction of the financial potential of the main institutional sectors of the economy, which include financial corporations (banks, insurance organizations, non-state pension funds and other investment companies), non-financial corporations (enterprises of various types of economic activity), government sector, households and foreign institutions. This model characterizes the multifaceted processes of transferring investment resources between sectors. It allows to establish the patterns of their reproduction during periods of recession and economic recovery, as well as to form predictive scenarios for the reproduction of the investment potential of the sectors and assess their impact on the dynamics of the economic stability of the territory.
\end{abstract}

\section{Introduction}

The scenario approach to forecasting the economic sustainability of territorial systems has significant advantages over other approaches. The formation of a whole system of predictive scenarios, in contrast to classical forecasting methods, allows not only to accurately assess the socio-economic, financial stability of a territory, but also to predict its possible change in the future under the influence of various internal and external uncertain factors. This approach allows to prepare in advance for adverse scenarios and form a system of mechanisms to prevent their implementation. The purpose of this study is to form a methodological approach to the design of a scenario model that reflects the processes of reproduction of the financial potential of various sectors of the economy at the regional level and makes it possible to predict the threat of losing the stability of the economic development of the territory. The stability of any socio-economic system and such a complex one as a region is determined, first of all, by the balanced development of its financial potential. At the same time, the stability of the territory is characterized not only by budgetary security, but also by the sufficiency of financial resources of its institutional sectors: financial corporations (banking sector, insurance organizations, non-state pension funds, investment companies), non-financial corporations (enterprises of various types of

*Corresponding author: ilia_naumov@list.ru 
activity), the government sector, households and foreign institutions. The balance of their financial potential forms the stability of the territorial system, and the disproportions that arise in its reproduction indicate the threat of loss of this stability. The formed balance model of the reproduction of the financial potential of the sectors makes it possible to identify negative trends in the movement of resources between non-financial, financial corporations, government sector, and households, destabilizing the economic development of the region. The initial work on the formation of a balance model of reproduction of the financial potential of interconnected institutional sectors was implemented in 1923 by P.I. Popov. He formed the balance of the national economy of the USSR for 1923-1924, which reflected the processes of transferring financial resources between sectors and identified threats to the loss of stability of the socio-economic development of territorial systems. This balance reflected the relationship between enterprises in various sectors of the economy, state and municipal institutions, the population and the world economy. The developed model did not reveal the features of reproduction of the financial potential of the financial corporations sector, as well as the features of the movement of resources between territorial systems.Interindustry balance model V.V. Leontiev [2], as a result of using the regression analysis method, made it possible to most accurately characterize the processes of formation and use of the social product in the sectoral context, as well as inter-sectoral production relationships between institutional sectors at the macroeconomic level. However, due to the limited statistical data, this model did not allow to study the processes of movement of financial resources between institutional sectors at the regional and municipal levels and the peculiarities of reproduction of their financial potential.Balance model of Eidelman M.R. [3] reflected the processes of reproduction of the aggregate social product in a fairly wide range of sectors of the national economy. However, due to the use of the method of selective statistical research, the model did not allow to accurately describe the processes of movement of financial resources and predict the stability of the socio-economic development of the territory. The construction of the model was based on the accounting data of only $20 \%$ of enterprises.

The models formed using the methodology of the System of National Accounts did not take into account the peculiarities of the movement of financial resources between sectors for financial derivatives. They did not disclose the regional features of the reproduction of the financial potential of institutional sectors, and also had serious errors due to incorrectly generated data by the federal statistics service. These models do not allow predicting changes in the reproduction processes of the financial potential of the sectors due to the large time lag in the publication of statistical data on the System of National Accounts.

Designed models by Stone R. [4], Pyatt G., Round J.I. [5], Defourny J., Thorbecke E. [6], Khan H., Thorbecke E. [7], Chowdhury A., Kirkpatrick C. [8], Chowdhury A., Kirkpatrick C. [9], using the Social Account Matrix (SAM) methodologydo not allow studying the features of the spatial movement of financial resources of institutional sectors. Their study is of paramount importance in assessing the socio-economic sustainability of territorial systems. The transfer of financial resources of sectors to another territorial system leads not only to a reduction in the financial opportunities for its development, but also to a decrease in the financial foundations of the socio-economic development of a given territory.This directly affects its development sustainability. The creation of a reliable scenario model that would allow reflecting the features of reproduction of the financial potential of institutional sectors requires the development of a new methodological approach. This methodological approach, in our opinion, should be based on the use of primary data of institutional units that form the sector of financial and non-financial corporations, government, households and foreign institutions, on the movement of financial resources, and should also use the methods of forming balance models, regression and spatial analysis. 


\section{Methods}

To form a scenario model for reproducing the financial potential of institutional sectors at the regional level, we have developed a methodological approach. The main stages of this approach are: 1) designing a balance model of the movement of financial resources between institutional sectors for investment instruments; 2) analysis of factors and patterns of reproduction of their investment potential; 3) modeling the processes of movement of financial resources between sectors, taking into account the influencing factors; 4) scenario forecasting of changes in the dynamics of "control variables" and the formation of basic scenarios for the reproduction of the financial potential of the sectors.

The methodological features of the formation of a balance model of the movement of financial resources between institutional sectors for various investment instruments are presented in detail in our work [10]. To form this model, we use the methodology for designing equilibrium models of the movement of financial resources between sectors and the principle of "double entry" of the System of National Accounts. According to this principle, each operation for the transfer of financial resources is displayed simultaneously in two sectors. One of them initiates the transfer of funds when carrying out financial transactions, and the other accepts them. We propose the formation of the active and passive parts of the balance sheet model by systematizing the primary data of the financial statements according to Form No. 101 of credit institutions registered in regional systems. Banks and other credit institutions are a connecting element in the processes of movement of financial resources between institutional sectors. Therefore, the information presented in this form allows for a detailed and accurate display of the features of the formation and use of the financial potential of institutional sectors for various investment instruments (investments in monetary gold, foreign currency, debt securities, stocks, financial derivatives, etc.). This information makes it possible to form a model both at the regional and federal levels.

The use of the double entry principle of the System of National Accounts will allow to represent the processes of movement of financial resources between sectors in a balanced matrix form. At the same time, the active part of the balanced model will reveal the features of the formation of financial potential by the sectors of non-financial corporations, government, households, foreign institutions sector, as well as the features of its use by the sector of financial corporations. The passive part of the model will reveal the features of the formation of the investment potential of financial corporations. In the model being formed, not the active and passive parts of each institutional sector are balanced, but the processes of movement of financial resources between them for various investment instruments. The balanced model formed in this way will allow at the next stage to reveal the features of the reproduction of the financial potential of institutional sectors in interconnection with each other, as well as to assess the financial stability of the territorial system as a whole.

In the process of scenario modeling, we propose to build a system of functional equations that reflect the relationships between institutional sectors in the processes of movement of financial resources for various investment instruments using the least squares method. In addition, we assume the formation of a regression model of the dependence of the processes of reproduction of financial potential on the factors of the internal and external environment (control variables). The constructed scenario model will become the basis for designing a whole system of various forecast scenarios for reproducing the financial potential of institutional sectors. The formation of a set of alternative scenarios using the Monte Carlo random number generator method for transforming the processes of financial resources movement between sectors with an assessment of their impact on the financial stability of the territorial system is the main advantage of the scenario approach. 
To form the most probable predictive scenarios for the reproduction of the financial potential of institutional sectors (optimistic, inertial and pessimistic), we propose to use the Arima method.This method will allow us to simulate the dynamics of changes in control variables affecting the processes of financial flows between sectors.Understanding the most probable trajectories of movement of financial resources between sectors and the processes of reproduction of their financial potential in the future will allow us to assess the prospects for changes in the economic stability of the territory and develop mechanisms for regulating emerging negative trends.

\section{Analysis of the processes of reproduction of the investment potential of institutional sectors}

We tested the developed methodological approach in the formation of a balance model of reproduction of the financial potential of institutional sectors in almost all constituent entities of the Russian Federation for the period from 1999 to 2018. Let us consider the features of the movement of financial resources between institutional sectors and the reproduction of their financial potential during periods of economic downturns and economic recovery using the example of the central subject of the Russian Federation - the city of Moscow. Formation of the balance model in dynamics for the period from 1998 to 2019 allowed to establish negative patterns of reproduction of the financial potential of institutional sectors during periods of economic recession 1998, 2003, 2008, 2014-2019:

1. The resources of institutional sectors accumulated by financial corporations were actively moving abroad in the form of investments in debt securities of foreign issuers, lending to foreign enterprises (Table 1).

Table 1. Balance model of reproduction of financial potentialinstitutional sectors in Moscow in 2014, billion rubles.

\begin{tabular}{|c|c|c|c|c|c|c|c|}
\hline \multirow[b]{2}{*}{$\begin{array}{l}\text { Investment } \\
\text { instruments }\end{array}$} & \multicolumn{3}{|c|}{ Financial corporations } & \multirow[b]{2}{*}{$\begin{array}{l}\text { Govern } \\
\text {-ment } \\
\text { sector }\end{array}$} & \multirow[b]{2}{*}{$\begin{array}{c}\text { Non- } \\
\text { financial } \\
\text { corporations }\end{array}$} & \multirow[b]{2}{*}{$\begin{array}{l}\text { Househo } \\
\text { lds }\end{array}$} & \multirow[b]{2}{*}{$\begin{array}{l}\text { Foreign } \\
\text { institutions } \\
\text { sector }\end{array}$} \\
\hline & $\begin{array}{c}\text { Cent } \\
\text { ral } \\
\text { Bank }\end{array}$ & $\begin{array}{c}\text { Bankin } \\
\text { g } \\
\text { sector }\end{array}$ & $\begin{array}{c}\text { Other } \\
\text { financial } \\
\text { institutions }\end{array}$ & & & & \\
\hline $\begin{array}{l}\text { Investments in } \\
\text { monetary gold }\end{array}$ & 24,2 & 55,9 & 4,1 & $-2,2$ & $-2,2$ & $-26,0$ & $-53,9$ \\
\hline $\begin{array}{l}\text { Investments in } \\
\text { foreign currency }\end{array}$ & 19,8 & 307,4 & 107,8 & 4,0 & 3,0 & $-184,1$ & -258 \\
\hline Deposits & -215 & 6549,5 & $-352,8$ & $-885,6$ & $-2546,7$ & $-1786,9$ & -762 \\
\hline $\begin{array}{l}\text { Investments in } \\
\text { debt securities }\end{array}$ & $\begin{array}{c}252, \\
6\end{array}$ & $\begin{array}{c}- \\
2246,6\end{array}$ & 553,0 & 441,3 & 292,2 & $-88,4$ & 796,0 \\
\hline Lending & $\begin{array}{c}- \\
2428 \\
\end{array}$ & $\begin{array}{c}- \\
4426,0 \\
\end{array}$ & 319,0 & 314,4 & 3649,2 & 1371,9 & 1199 \\
\hline $\begin{array}{l}\text { Investments in } \\
\text { derivative } \\
\text { financial } \\
\text { instruments }\end{array}$ & 0,0 & $\begin{array}{c}- \\
1968,4\end{array}$ & 1968,4 & 0 & 0 & 0 & 0 \\
\hline Investing in stocks & $-29,4$ & 6591,3 & $-1919,3$ & $-1266,9$ & $-1454,5$ & $-989,0$ & -932 \\
\hline $\begin{array}{l}\text { Debt, including } \\
\text { overdue }\end{array}$ & $-14,4$ & $-320,2$ & $-30,7$ & $-19,0$ & 123,6 & 234,8 & 25,8 \\
\hline $\begin{array}{l}\text { Payments for } \\
\text { taxes and duties }\end{array}$ & 0 & 19,1 & 0 & $-19,1$ & 0 & 0 & 0 \\
\hline Payment of wages & 0 & $-12,2$ & 0 & 0 & 0,0 & 12,2 & 0 \\
\hline $\begin{array}{l}\text { Settlements with } \\
\text { suppliers }\end{array}$ & 0 & $\begin{array}{c}- \\
4471,7\end{array}$ & $-0,4$ & 0 & 4476,0 & 0 & $-3,9$ \\
\hline $\begin{array}{l}\text { Investment in } \\
\text { fixed assets }\end{array}$ & 0 & $-78,0$ & 1,8 & $-15,7$ & 64,8 & 27,0 & 0 \\
\hline TOTAL & $\begin{array}{c}- \\
2391\end{array}$ & 0 & 650,9 & $-1448,7$ & 4605,5 & $-1428,7$ & 11,6 \\
\hline
\end{tabular}


Thus, the model of reproduction of the financial potential of the sectors formed according to 2014 showed the movement of a significant amount of resources abroad in the form of investments in debt securities of foreign issuers (796 billion rubles). At the same time, there was a significant reduction in investments of financial institutions in government securities and securities of non-financial corporations. The level of lending to foreign enterprises was significant (1199 billion rubles).

2. Financial corporations carried out a significant amount of speculative transactions with financial derivatives. So, according to 2014 data, the volume of such investments amounted to 1968.4 billion rubles.

3. Instead of financial support for the real sector of the economy and state enterprises by attracting additional investments in equity securities (shares), financial institutions in the region were actively getting rid of previously acquired shares.

4. During periods of economic downturn, tax arrears of financial corporations increased significantly. In 2014, the amount of unpaid taxes amounted to 19.1 billion rubles.

As a result of these regularities, during periods of economic downturns, the financial potential of individual institutional sectors, for example, government, households and financial corporations, sharply declined, and there was a significant outflow of capital abroad (Table 2).

Table 2. Dynamics of reproduction of financial potentialinstitutional sectors in Moscow for the period 1999-2019, billion rubles

\begin{tabular}{|c|c|c|c|c|c|c|}
\hline & \multicolumn{2}{|c|}{ Financial corporations } & Government & $\begin{array}{c}\text { Non- } \\
\text { financial } \\
\text { corporations }\end{array}$ & Households & $\begin{array}{c}\text { Foreign } \\
\text { institutions } \\
\text { sector }\end{array}$ \\
\hline 1998 & 11,4 & $-27,7$ & $-20,6$ & 55,3 & $-15,3$ & $-3,1$ \\
\hline 1999 & $-8,0$ & 11,6 & 8,0 & 7,8 & $-0,8$ & $-18,6$ \\
\hline 2000 & 30,5 & $-41,1$ & 7,2 & 19,7 & $-9,3$ & $-7,1$ \\
\hline 2001 & 17,7 & $-35,0$ & $-23,1$ & 51,0 & $-9,7$ & $-0,9$ \\
\hline 2002 & 132,6 & $-309,7$ & 362,8 & 736,7 & $-887,7$ & $-34,7$ \\
\hline 2003 & 160,5 & $-38,9$ & 57,3 & 56,6 & $-156,2$ & $-79,4$ \\
\hline 2004 & $-13,2$ & 36,9 & $-133,8$ & 358,4 & $-105,8$ & $-142,5$ \\
\hline 2005 & $-200,8$ & 67,1 & 115,4 & 396,7 & $-186,4$ & $-192,0$ \\
\hline 2006 & 32,7 & $-81,2$ & $-175,8$ & 865,0 & $-104,2$ & $-536,5$ \\
\hline 2007 & $-89,5$ & $-336,6$ & $-162,6$ & 1309,7 & $-161,1$ & $-559,9$ \\
\hline 2008 & $-1028,9$ & $-1545,7$ & $-2096,2$ & 6578,9 & $-834,7$ & $-1073,4$ \\
\hline 2009 & 862,7 & $-964,2$ & 12,9 & 1389,4 & $-2282,1$ & 981,3 \\
\hline 2010 & 1401,7 & 191,7 & 665,1 & $-1222,7$ & $-1256,4$ & 220,6 \\
\hline 2011 & $-1004,4$ & 11,7 & $-1015,6$ & 2277,8 & $-527,7$ & 258,4 \\
\hline 2012 & $-1299,9$ & $-1000,7$ & $-207,5$ & 2461,1 & $-118,4$ & 165,5 \\
\hline 2013 & $-460,9$ & $-710,3$ & $-364,9$ & 2378,4 & $-764,4$ & $-77,9$ \\
\hline 2014 & $-2390,7$ & 650,9 & $-1448,7$ & 4605,5 & $-1428,7$ & 11,6 \\
\hline 2015 & 2042,4 & $-2487,9$ & $-2591,6$ & 6211,1 & $-3846,5$ & 672,4 \\
\hline 2016 & 3019,9 & 443,8 & 1602,1 & $-2625,8$ & $-1256,7$ & $-1183,3$ \\
\hline 2017 & 1139,0 & 1776,7 & 826,5 & $-3128,5$ & $-1444,0$ & 830,3 \\
\hline 2018 & 856,3 & $-901,5$ & $-2138,9$ & 1325,6 & 230,2 & 628,2 \\
\hline 2019 & 77,3 & $-2,8$ & $-1480,9$ & $-144,9$ & $-292,9$ & 1844,2 \\
\hline
\end{tabular}

To restore the financial corporations sector, which has accumulated funds from other institutional sectors, the Central Bank provided significant financial support during the crisis (1029 billion rubles in 2008 and 2391 billion rubles in 2009). However, the allocated financial resources by credit institutions were not used to support the real sector of the economy and the government sector.As a result, the economic recovery processes were delayed, the institutional sectors did not have sufficient financial potential for this. The formed balance model of the reproduction of the financial potential of the sectors showed that the deficit of financial resources in the institutional sectors is still observed. The 
outflow of financial resources of institutional sectors abroad has reached record levels over the past three years. And this creates serious threats to the financial stability of the region.The periods of economic recovery, on the contrary, were characterized by a significant inflow of financial resources from abroad. Until 2008, there was a negative balance in the "rest of the world" sector, which indicated the active attraction of foreign investments into the economy. As a result, the government and household sectors did not experience a severe financial shortage as they did during the economic downturn.

Table 3. Scenario model of reproduction of the financial potential of institutional sectors in Moscow

\begin{tabular}{|c|c|c|c|c|c|c|c|}
\hline & \multicolumn{3}{|c|}{ Financial corporations } & \multirow[b]{2}{*}{$\begin{array}{c}\text { Government } \\
\text { sector }(\mathbf{G})\end{array}$} & \multirow[b]{2}{*}{$\begin{array}{l}\text { Non- } \\
\text { financial } \\
\text { corporati } \\
\text { ons }(\mathrm{NF})\end{array}$} & \multirow[b]{2}{*}{$\begin{array}{c}\text { House } \\
\text { holds } \\
\text { (H) }\end{array}$} & \multirow[b]{2}{*}{$\begin{array}{c}\text { Foreign } \\
\text { institutio } \\
\text { ns sector } \\
\text { (F) }\end{array}$} \\
\hline & $\begin{array}{c}\text { Central } \\
\text { Bank } \\
\text { (CB) }\end{array}$ & $\begin{array}{c}\text { Banking } \\
\text { sector } \\
\text { (BS) }\end{array}$ & $\begin{array}{c}\text { Other } \\
\text { financial } \\
\text { institutio } \\
\text { ns (FI) }\end{array}$ & & & & \\
\hline $\begin{array}{l}\text { Investments } \\
\text { in monetary } \\
\text { gold(MG) }\end{array}$ & & & $\begin{array}{c}\mathrm{FI}_{\mathrm{MG}}=- \\
0,492 * \mathrm{BS} \\
\mathrm{MG}\end{array}$ & $\begin{array}{c}\mathrm{G}_{\mathrm{MG}}=- \\
0,254 * \mathrm{BS}_{\mathrm{MG}}\end{array}$ & $\begin{array}{c}\mathrm{NF}_{\mathrm{MG}}=- \\
0,254 * \mathrm{BS} \\
\mathrm{MG}\end{array}$ & & \\
\hline $\begin{array}{l}\text { Investments } \\
\text { in foreign } \\
\text { currency } \\
\text { (FC) }\end{array}$ & $\begin{array}{c}\mathrm{CB}_{\mathrm{FC}}=0,0 \\
29 * \mathrm{BS}_{\mathrm{FC}}\end{array}$ & & & $\begin{array}{c}\mathrm{G}_{\mathrm{FC}}=- \\
0,006^{*} \mathrm{BS}_{\mathrm{FC}}\end{array}$ & & $\begin{array}{c}\mathrm{H}_{\mathrm{FC}}=- \\
0,704 * \\
\mathrm{BS}_{\mathrm{FC}}\end{array}$ & $\begin{array}{c}\mathrm{F}_{\mathrm{FC}}=- \\
0,319 * \mathrm{BS} \\
\mathrm{FC}\end{array}$ \\
\hline Deposits(D) & & $\begin{array}{c}\mathrm{BS}_{\mathrm{D}}=5723 \\
85597 * \mathrm{R} \\
\mathrm{D}- \\
15666924 \\
8 * \mathrm{RCB}\end{array}$ & $\begin{array}{c}\mathrm{FI}_{\mathrm{D}}=- \\
0,08 * \mathrm{BS}_{\mathrm{D}}\end{array}$ & $\begin{array}{c}\mathrm{G}_{\mathrm{D}}=- \\
0,166^{*} \mathrm{BS}_{\mathrm{D}}\end{array}$ & $\begin{array}{c}\mathrm{NF}_{\mathrm{D}}=- \\
0,375^{*} \mathrm{BS} \\
\mathrm{D}\end{array}$ & $\begin{array}{c}\mathrm{H}_{\mathrm{D}}=- \\
0,379 * \\
\mathrm{BS}_{\mathrm{D}}\end{array}$ & \\
\hline $\begin{array}{l}\text { Investments } \\
\text { in debt } \\
\text { securities(D } \\
\text { C) }\end{array}$ & $\begin{array}{c}\mathrm{CB}_{\mathrm{DC}}=- \\
0,226^{*} \mathrm{BS} \\
\mathrm{DC}\end{array}$ & $\begin{array}{c}\mathrm{BS}_{\mathrm{DC}}=186 \\
82102 * \\
\mathrm{RCB}- \\
36591901 \\
* \mathrm{VIX}\end{array}$ & $\begin{array}{c}\mathrm{FI}_{\mathrm{DC}}=- \\
0,119 * \mathrm{BS} \\
\mathrm{DC}\end{array}$ & $\begin{array}{c}\mathrm{G}_{\mathrm{DC}}=- \\
0,311 * \mathrm{BS}_{\mathrm{DC}}\end{array}$ & $\begin{array}{c}\mathrm{NF}_{\mathrm{DC}}=- \\
0,125^{*} \mathrm{BS} \\
\mathrm{DC}\end{array}$ & & $\begin{array}{c}\mathrm{F}_{\mathrm{DC}}=- \\
0,219 * \mathrm{BS} \\
\text { DC }\end{array}$ \\
\hline Lending(L) & & & $\begin{array}{c}\mathrm{FI}_{\mathrm{L}}=- \\
0,149 * \mathrm{BS} \\
\mathrm{L}\end{array}$ & $\begin{array}{c}\mathrm{G}_{\mathrm{L}}=- \\
0,026 * \mathrm{BS}_{\mathrm{L}}\end{array}$ & $\begin{array}{c}\mathrm{NF}_{\mathrm{L}}=- \\
0,509 * \mathrm{BS} \\
\mathrm{L}\end{array}$ & $\begin{array}{c}\mathrm{H}_{\mathrm{L}}=- \\
0,316^{*} \\
\mathrm{BS}_{\mathrm{L}}\end{array}$ & \\
\hline $\begin{array}{l}\text { Investments } \\
\text { in derivative } \\
\text { (FD) }\end{array}$ & & $\begin{array}{c}\mathrm{BS}_{\mathrm{FD}}=187 \\
9220,7 * \mathrm{R} \\
\mathrm{TS}- \\
2497262,7 \\
* \mathrm{MICEX} \\
+7333233 \\
, 9 * \mathrm{CBV}\end{array}$ & $\begin{array}{c}\mathrm{FI}_{\mathrm{FD}}=- \\
\mathrm{BS}_{\mathrm{FD}}\end{array}$ & & & & \\
\hline $\begin{array}{l}\text { Investing in } \\
\text { stocks(S) }\end{array}$ & & & $\begin{array}{c}\mathrm{FI}_{\mathrm{S}}=- \\
0,226^{*} \mathrm{BS} \\
\mathrm{s}\end{array}$ & $\begin{array}{c}\mathrm{G}_{\mathrm{S}}=- \\
0,207 * \mathrm{BS}_{\mathrm{S}}\end{array}$ & $\begin{array}{c}\mathrm{NF}_{\mathrm{S}}=- \\
0,231 * \mathrm{BS} \\
\mathrm{S}\end{array}$ & $\begin{array}{c}\mathrm{H}_{\mathrm{S}}=- \\
0,177 * \\
\mathrm{BS}_{\mathrm{S}}\end{array}$ & $\begin{array}{c}\mathrm{F}_{\mathrm{S}}=- \\
0,159 * \mathrm{BS} \\
\mathrm{S}\end{array}$ \\
\hline $\begin{array}{l}\text { Debt, } \\
\text { including } \\
\text { overdue(OD) }\end{array}$ & $\begin{array}{c}\mathrm{CB}_{\mathrm{OD}}=0,0 \\
48 * \mathrm{BS}_{\mathrm{OD}}\end{array}$ & & & & $\begin{array}{c}\mathrm{NF}_{\mathrm{OD}}=- \\
0,743 * \mathrm{BS} \\
\mathrm{OD}\end{array}$ & $\begin{array}{c}\mathrm{H}_{\mathrm{OD}}=- \\
0,21 * \mathrm{~B} \\
\mathrm{~S}_{\mathrm{OD}}\end{array}$ & $\begin{array}{c}\mathrm{F}_{\mathrm{OD}}=- \\
0,095 * \mathrm{BS} \\
\mathrm{OD}\end{array}$ \\
\hline $\begin{array}{l}\text { Payments for } \\
\text { taxes and } \\
\text { duties(T) }\end{array}$ & & & & $\mathrm{G}_{\mathrm{T}}=-\mathrm{BS}_{\mathrm{T}}$ & & & \\
\hline $\begin{array}{l}\text { Payment of } \\
\text { wages (PW) }\end{array}$ & & & & $\begin{array}{c}\mathrm{G}_{\mathrm{PW}}=- \\
0,143^{*} \mathrm{BS}_{\mathrm{PW}}\end{array}$ & & $\begin{array}{c}\mathrm{H}_{\mathrm{PW}}=- \\
0,857^{*} \\
\mathrm{BS}_{\mathrm{PW}}\end{array}$ & \\
\hline $\begin{array}{l}\text { Settlements } \\
\text { with } \\
\text { suppliers(SS) }\end{array}$ & & & $\begin{array}{c}\mathrm{FI}_{\mathrm{SS}}=0,00 \\
1 * \mathrm{BS}_{\mathrm{SS}}\end{array}$ & & $\begin{array}{c}\mathrm{NF}_{\mathrm{SS}}=- \\
1,002 * \mathrm{BS} \\
\mathrm{sS}\end{array}$ & & $\begin{array}{c}\mathrm{F}_{\mathrm{SS}}=0,001 \\
\quad * \mathrm{BS}_{\mathrm{SS}}\end{array}$ \\
\hline $\begin{array}{l}\text { Investment } \\
\text { in fixed } \\
\text { assets(FA) }\end{array}$ & & $\begin{array}{l}\mathrm{BS}_{\mathrm{FA}}=- \\
4,05 * \mathrm{~A}\end{array}$ & & $\begin{array}{c}\mathrm{G}_{\mathrm{FA}}=- \\
0,301 * \mathrm{BS}_{\mathrm{FA}}\end{array}$ & $\begin{array}{c}\mathrm{NF}_{\mathrm{FA}}=- \\
0,522 * \mathrm{BS} \\
\mathrm{FA}\end{array}$ & $\begin{array}{c}\mathrm{H}_{\mathrm{FA}}=- \\
0,177 * \\
\mathrm{BS}_{\mathrm{FA}}\end{array}$ & \\
\hline
\end{tabular}

$\mathrm{RD}$ - Rate on deposits of individuals in rubles, $\%$; RCB - Key rate of the Central Bank of Russia,\%; VIX - Volatility Index S\&P 500 VIX,\%; RTS - Absolute growth of the RTS 
Index (RTSI), rubles; CBV - Absolute growth of the corporate bond value index (RUCBITR), rubles; MICEX - Absolute growth of the MICEX index, rubles; A - Cost of fixed assets of enterprises in Moscow at the end of the year, million rubles.

To predict the possible transformation of the processes of reproduction of the financial potential of institutional sectors, we built a scenario model using the least squares method.This model is a system of functional equations that reflect the relationship between sectors in the processes of movement of financial resources for various investment instruments, as well as the influence of factors of the internal and external environment (Table 3). In the course of regression analysis of the processes of movement of financial resources between sectors for the period from 1998 to 2019, we established control variables, the change of which allows us to generate active forecast scenarios. These variables include: the interest rate on deposits of individuals, the key rate of the Central Bank of the Russian Federation, the volatility index in the stock market, the RTS and MICEX indices, the cost of corporate bonds, the cost of fixed assets in Moscow.These variables made it possible to design predictive scenarios for the movement of financial resources between sectors for investments in debt securities, derivative financial instruments, and fixed assets. For the rest of the investment instruments, forecast scenarios were built using ARIMA modeling. As a result of testing the scenario model for reproducing the financial potential of the sectors, we have developed basic forecast scenarios (Table 4).

Table4. Inertial (IS), pessimistic (PS), optimistic (OS) scenarios for the reproduction of the financial potential of institutional sectors in Moscow, billion rubles

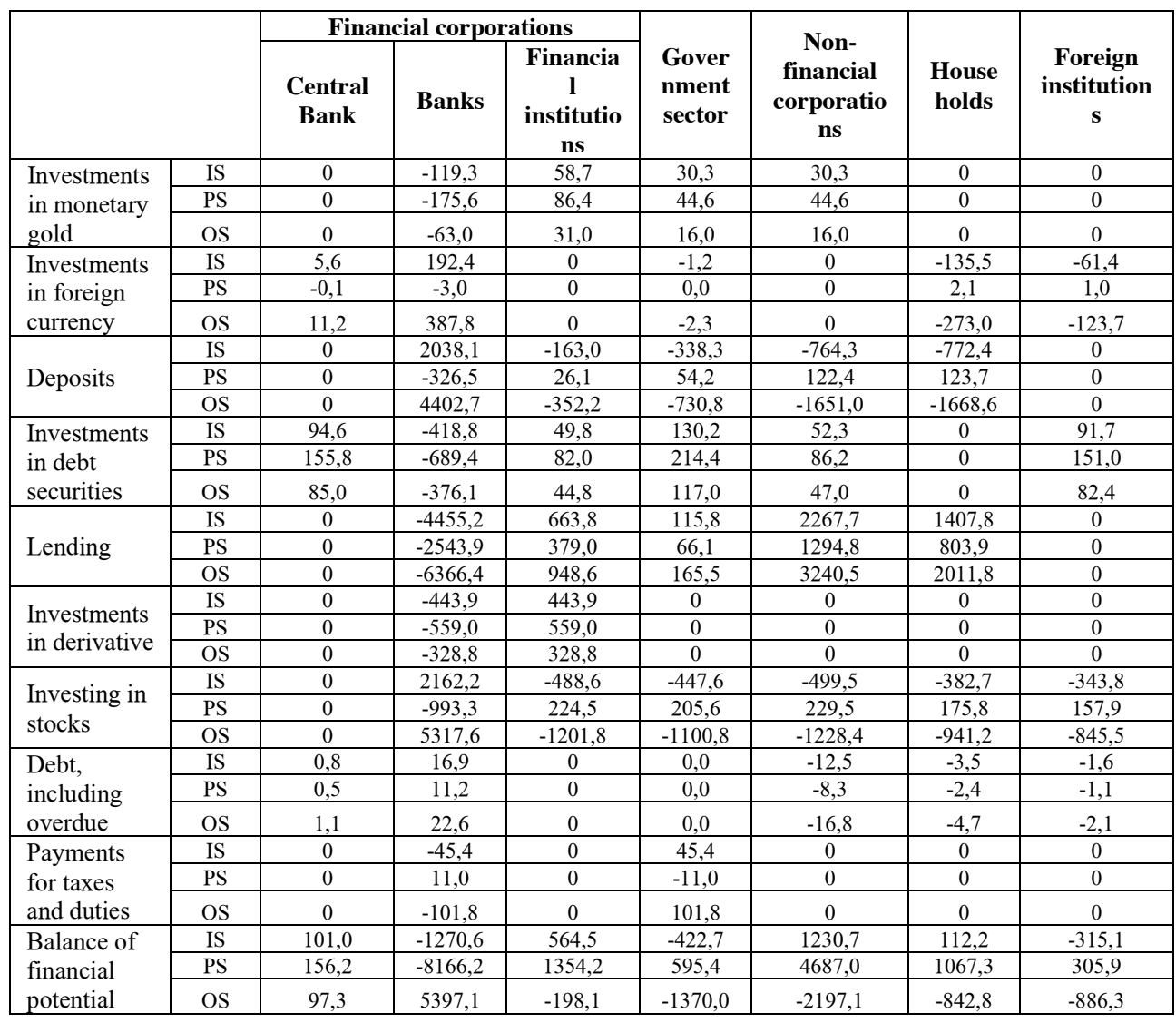


The projected inertial scenario assuming the continuation of the current trends made it possible to predict a possible inflow of foreign investments in government and corporate shares in the amount of 343.8 billion rubles. This scenario made it possible to forecast an increase in lending to households (by 1408 billion rubles) and enterprises in the real sector of the economy (by 2267 billion rubles). The inertial scenario is moderately optimistic, as it assumes an inflow of foreign investments into the region's economy in the amount of 315.1 billionrubles.On the other hand, this scenario creates threats to the financial stability of the sectors due to increased investment in highly risky derivatives (443.9 billionrubles). The pessimistic scenario of the transformation of the processes of reproduction of the financial potential of the sectors presupposes the intensification of speculative investment activity of the institutional sectors. In particular, it assumes a reduction in investments in government debt securities (214 billion rubles) and corporate securities ( 86 billion rubles) and an increase in investments in securities of foreign issuers (151 billion rubles). This scenario predicts a reduction in the inflow of foreign investment in shares of state institutions, enterprises of the real sector of the economy and an increase in investment in foreign shares (158 billion rubles). In addition, it is possible to withdraw funds from bank deposits by enterprises up to 122 billion rubles and households (124 billion rubles). The pessimistic scenario assumes a significant reduction in lending to households and enterprises in the real sector of the economy, as well as a significant increase in investments by financial institutions in such highly volatile financial derivatives as futures and options (559 billion rubles). The implementation of the pessimistic scenario will lead to debt of financial corporations in taxes and fees to the public administration sector (11 billion rubles), an increase in the debt of financial institutions for payment of wages (54 billion rubles) and social insurance contributions (9 billion rubles) and the overall outflow of financial resources abroad in the amount of 306 billion rubles.

\section{Conclusions}

1. The balance model of reproduction of the financial potential of institutional sectors made it possible to identify the features of the movement of financial resources between sectors during periods of economic downturns and economic recovery. The model helped to establish investment instruments for which during periods of economic downturns the outflow of financial resources abroad was carried out. This model made it possible to determine the volume of reduction in the financial potential of institutional sectors.

2. The recent processes of movement of financial resources between sectors indicate a reduction in their financial potential and a decrease in the economic stability of the region.

3. The scenario model developed in the course of the regression analysis made it possible to design the most probable forecast scenarios for the reproduction of the financial potential of institutional sectors by 2021 .

\section{Acknowledgements}

The study was carried out with the financial support of the Russian Foundation for Basic Research, project No. 19-010-00660 "Scenario design of a model for reproducing the investment potential of institutional sectors in the regional system".

\section{References}

1. P.I. Popov, Balance of the National Economy of the USSR 1923-1924, (1993)

2. V.V. Leontiev, Planned economy, 12 (1925) 
3. M.R. Eidelman, Interindustry Balance of the Social Product, (1966)

4. R. Stone, Review of Income and Wealth, 1 (1951)

5. G. Pyatt, J.I. Round, Economic J., 89 (1979)

6. J. Defourny, E. Thorbecke, Economic J., 94 (1984)

7. H. Khan, E. Thorbecke, J. Policy Modeling, 11 (1989)

8. A. Chowdhury, C. Kirkpatrick, Development Policy and Planning: An Introduction to Models and Techniques, (1994)

9. C. Hayden, J.I. Round, World Development, 10 (1982)

10. I.V. Naumov, Fin.: Theory and Practice, 5 (2019)

11. I. V. Naumov, J. of Econ. Theory, 4 (2019) 